Vol. 7(1998): 197-206.

\title{
Contribution of livestock to food production in developing countries
}

Hank Fitzhugh

International Livestock Research Institute, PO Box 30709, Nairobi, Kenya, e-mail: h.fitzhugh@cgnet.com

On a global basis, livestock products - meat, milk, eggs and fibre - account for $40 \%$ of the value of total marketed agricultural product. Animal products provide essential amino acids, vitamins and minerals to help ensure nutritionally balanced diets. In developing countries, livestock traction and manure also contribute to food production through improved cultivation and soil fertility which increase crop yields. On average, the proportional contribution of livestock product to dietary calories and protein in developed countries is double that for developing countries. Demand for livestock products is fuelled by the population increase, income growth and urbanisation in developing countries. Therefore, over the past decade, consumption of livestock product has sharply increased in developing countries, while slightly decreasing in developed countries where consumption is already relatively high on average. Increased demand in developing countries increases income for producers, but also stresses the environment through pollution, soil erosion, overgrazing and deforestation. Research involving global partnerships of scientists and institutes can help ensure that the increased demands for livestock product in developing countries will be met in economically feasible and environmentally sustainable ways.

Key words: developing countries, dietary quality, food systems, future demand, livestock

\section{Introduction}

Livestock have often been denigrated as competitors for human food and degraders of the natural resources required for food production. In fact, livestock are most often complementary components of food production systems. Livestock can convert otherwise unused feeds to highly desired human food. In developing regions, livestock are principal sources of draft power and manure to enhance crop production. For example, in sub-Saharan Africa the farm level values of draft power and manure add almost $50 \%$ to the total economic contribution of livestock to total agricultural value (Winrock 1992). This paper provides an overview of the role of livestock in meeting the food needs in develop- 


\section{AGRICULTURAL AND FOOD SCIENCE IN FINLAND}

\section{Seminar in honour of the 100th anniversary of MTT}

ing countries - directly through meat, milk and eggs and indirectly through improved crop productivity.

\section{Food-producing livestock}

On a global basis, livestock products - meat, milk, eggs and fibre - constitute about $40 \%$ of the marketed value of total agricultural product. This proportional contribution is about $50 \%$ for developed regions and $25 \%$ for developing regions (USDA 1990). The principal food-producing livestock species include:

Poultry - chickens, turkeys, ducks, geese and other fowl

\section{Mammals}

Monogastrics - swine, equine, rabbits and others

Ruminants - cattle, sheep, goats, buffalo, reindeer, yak and others

Camelids - camels, Ilamas, alpaca

The development of the livestock food-producing sector since 1950 has been remarkable. While human numbers have more than doubled, the numbers of poultry have grown from 3 to 12 billion and the numbers of food-producing mammals from 2.3 to over 4 billion.

Until the middle of this century, livestock and poultry were traditionally grazers and scavengers of non-competitive feed resources. Ruminants continue to depend primarily on forages, crop residues and other non-competitive fibrous feeds for the vast majority of their nutrients. However, in the past five decades, there has been a significant increase in grain feeding. This increase has fuelled the substantial growth in meat production since 1950 , but has been primarily limited to industrialised production systems for swine and poultry in developed countries (Sere and Steinfeld 1996).

Grain feeding to livestock, primarily swine and poultry, will continue to increase in developing countries. Some authors, including Brown
(1995), argue that these increases are not sustainable, that staple grain prices will increase, and that the world's poor will suffer. Others, including Delgado et al. (1998), are more optimistic about the potential for increasing grain feeding without major economic or environmental consequences.

\section{Contributions of livestock to food supply}

The food contributions of livestock have recently been summarised by Delgado et al. (1998). The authors also estimated future contributions using the IMPACT model developed by the International Food Policy Research Institute (Rosegrant et al. 1995). Tables 1, 2, 3 and 4 are adapted from those presented by Delgado et al. (1998).

The percentages of dietary calories and protein from animal products are summarised for developing and developed regions (Table 1). On average, the percentages for developed regions are more than double those for developing regions. However, there is a notable trend: in recent years the percentages have sharply increased in developing regions while slightly decreasing in developed regions. For livestock products, the growth market is in developing regions, where population increase, income growth and urbanisation combine to increase demand from the relatively low consumption levels which have prevailed in the past. Demand in developed regions has plateaued at what are already high levels of consumption of animal product.

The changes from 1973 to 1993 in the annual consumption per capita of selected products are shown in Table 2 for developed and developing regions. Consumption of pork and poultry meat has increased in all regions, but most dramatically in developing regions. Percentage increases are similarly dramatic for eggs and dairy products. Nevertheless, consumption per capita remains substantially less than in developed re- 


\section{AGRICULTURAL AND FOOD SCIENCE IN FINLAND}

Vol. 7 (1998): 197-206.

Table 1. Percentage of food calories and protein from animal products by year, 1973-1993.

\begin{tabular}{lcccccc}
\hline Region & \multicolumn{3}{c}{ Calories from animal products (\%) } & \multicolumn{3}{c}{ Protein from Animal Products (\%) } \\
& 1973 & 1983 & 1993 & 1973 & 1983 & 1993 \\
\hline Developing world & 8 & 9 & 11 & 19 & 21 & 26 \\
Developed world & 28 & 28 & 27 & 55 & 57 & 56 \\
World & 15 & 15 & 16 & 34 & 34 & 36 \\
\hline
\end{tabular}

Source: FAOSTAT 9/17/97.

Notes: "Animal products", according to the FAO definition, includes meat, dairy and egg products, and freshwater and marine animal products. Calculated from 3-year moving averages.

Adapted from Delgado et al. (1998).

Table 2. Annual per capita consumption $(\mathrm{kg})$ of selected livestock products by year.

\begin{tabular}{lrrrr}
\hline Livestock product & \multicolumn{2}{c}{ Developed regions } & \multicolumn{2}{c}{ Developing regions } \\
& 1973 & 1993 & 1973 & 1993 \\
\hline Beef & 26 & 25 & 4 & 5 \\
Mutton and goat & 3 & 3 & 1 & 1 \\
Pork & 26 & 29 & 4 & 9 \\
Poultry & 11 & 20 & 2 & 5 \\
Four meats & 67 & 78 & 11 & 21 \\
Eggs & 13 & 13 & 2 & 5 \\
Dairy products excluding butter & 188 & 195 & 29 & 40 \\
Four meats, eggs, dairy products & 268 & 286 & 42 & 66 \\
\hline
\end{tabular}

Sources:FAOSTAT 12/10/97 and Rosegrant et al. 1995.

Notes:"Four meats" comprises beef, pork, mutton and goat, and poultry.

Adapted from Delgado et al. (1998).

gions, suggesting room for considerable growth in future.

Past and projected trends for meat consumption are given in Table 3. Annual growth rates are predicted to decline from those observed between 1982 and 1993; however, the annual growth rates for developing regions continue to be about six times greater than those for developed regions. The consequences of these differential rates of growth are striking. By the year 2020 , total meat consumption in developing regions will increase from being $10 \%$ lower in 1993 to becoming $72 \%$ greater than in developed regions. Per capita consumption of meat will continue to be lower in developing regions but decreasingly so. These trends and their consequences are particularly striking for China. In
1993, total meat consumption for China was only slightly more than for the USA. but by the year 2020 , total meat consumption for China is expected to be more than double that for the USA. and approaching the total meat consumption for all developed countries combined.

Where will the meat to satisfy the increased demand be produced ? A related question is, where will the cereal grains to feed the swine and poultry be produced? Using results from the IMPACT model, which takes into account prices and production potential, Delgado et al. (1998) expect that the bulk of the increase in meat production will be within the same regions where the meat is consumed. However, the net balances for meat (and feed grain) trade are in favour of developed regions (Table 4). 


\section{AGRICULTURAL AND FOOD SCIENCE IN FINLAND}

\section{Seminar in honour of the 100th anniversary of MTT}

Table 3. Past and projected consumption trends of meat, to the year 2020.

\begin{tabular}{|c|c|c|c|c|c|c|c|c|}
\hline Region & $\begin{array}{l}\text { Annual growth } \\
\text { in meat } \\
\text { consumption, } \\
\text { 1982-1993, } \\
\text { \% per year }\end{array}$ & $\begin{array}{l}\text { Projected annual } \\
\text { growth in meat } \\
\text { consumption, } \\
\text { 1993-2020, } \\
\text { \% per year }\end{array}$ & \multicolumn{3}{|c|}{$\begin{array}{l}\text { Total meat consumption, } \\
\text { million metric tons }\end{array}$} & \multicolumn{3}{|c|}{$\begin{array}{l}\text { Per capita meat consumption, } \\
\text { kg }\end{array}$} \\
\hline Developing world & 5.3 & 2.9 & 50 & 89 & 194 & 15 & 21 & 31 \\
\hline China & 8.3 & 3.2 & 17 & 39 & 89 & 16 & 33 & 63 \\
\hline Developed world & 1.2 & 0.5 & 88 & 99 & 113 & 74 & 78 & 81 \\
\hline United States & 1.8 & 0.6 & 25 & 31 & 37 & 107 & 118 & 114 \\
\hline World & 2.8 & 1.8 & 139 & 188 & 306 & 30 & 34 & 40 \\
\hline
\end{tabular}

Sources: Annual growth in meat consumption, 1982-1993, is the compound growth rate from regressions fitted to FAO annual data (FAOSTAT 9/17/97).

Notes: "Consumption" is direct use as food, uncooked weight bone-in. "Meat" comprises beef, pork, mutton and goat, and poultry. Metric tons and kg are 3-year moving averages centred on the year shown.

Adapted from Delgado et al. (1998)

Table 4. Total meat production, consumption, and net trade.

\begin{tabular}{lcccrrr}
\hline Region & \multicolumn{2}{c}{ Consumption, } & \multicolumn{2}{c}{ Production, } & \multicolumn{2}{c}{ Net exports (imports), } \\
& \multicolumn{2}{c}{ million metric tons } & \multicolumn{2}{c}{ million metric tons } & \multicolumn{2}{c}{ million metric tons } \\
& 1993 & 2020 & 1993 & 2020 & 1993 & 2020 \\
\hline Developing world & 89 & 194 & 88 & 182 & -0.6 & -11.5 \\
Developed world & 99 & 112 & 100 & 124 & 0.6 & 11.5 \\
World & 188 & 306 & 188 & 306 & 0.0 & 0.0 \\
\hline
\end{tabular}

Notes: Net exports (imports) are defined as production minus consumption, subject to rounding error. Metric tons are 3-year averages centred on the year shown and refer to carcass weights.

Adapted from Delgado et al. (1998).

\section{Contribution to dietary quality}

Human preferences for meat and milk are well documented. As shown by Delgado et al. (1998), when livestock products are available and affordable, consumption increases. Lester Brown (1995), who has been a critic of the livestock industry, acknowledges this fact: "Even as population grows at a record pace, those with low incomes, who account for most of humanity and who typically depend on a starch staple, such as rice, for $70 \%$ or more of their calories, want to diversity their diets by consuming more livestock products. This desire to move up the food chain appears to be universal. In every society where incomes have risen, so has consumption of livestock products" (Brown 1995).

Most humans intuitively recognise the value of livestock products in a balanced diet. Milk and eggs set the standards against which dietary protein sources are measured for the mix of essential amino acids for body protein synthesis. Milk is especially valuable as a supplement to cereal diets. Without milk, less than $30 \%$ of cereal protein is used for growth. Meat products provide essential amino acids, iron, zinc, thiamine, riboflavin, vitamins $A, B_{6}$ and $B_{12}$ and other micronutrients (Fitzhugh et al. 1978).

The health concerns voiced in developed countries relate to over-consumption of livestock products and the putative relationships with heart 
Vol. 7 (1998): 197-206.

disease, stroke and cancer. Over-consumption is not the concern of the poor in developing countries; the concern is too little livestock product in the diet for good mental and physical development and health. The readily available essential amino acids and micronutrients from animal products are particularly valuable in the diets of children in poor urban households, where a limited choice of foods makes it difficult to obtain a nutritionally balanced diet.

\section{Livestock, soil fertility and crop yields}

In many developed countries, livestock manures are a pollutant and a problem. However, in most developing regions, livestock manures are key to improving nutrient management in resourcescarce cropping systems (ILRI 1997a). Longterm fertility trials in West Africa indicate the value of animal manures in strategic combination with chemical fertilisers (Fig. 1). In this 30year trial, chemical nitrogen-phosphorous-potassium (NPK) only maintained sorghum grain yields at one tonne per hectare. The addition of manure with NPK resulted in a substantial increase in sorghum yield and this increasing trend still continued after three decades.

The impact of livestock on the environment, including natural resource management in croplivestock systems, is a priority for research by the International Livestock Research Institute (ILRI). The processes of nutrient cycling from soils to plants and, through animals, back to the soils are being studied by ILRI scientists in the Sahelian region of West Africa. The Sahelian agropastoralists graze their livestock on common rangelands during the day. At night, the livestock are tethered on the croplands where most of the nutrients are consumed and ruminated during the day. Up to $95 \%$ of the nitrogen and phosphorous consumed is excreted by the tethered livestock: nitrogen in urine and faeces, phosphorous pri-

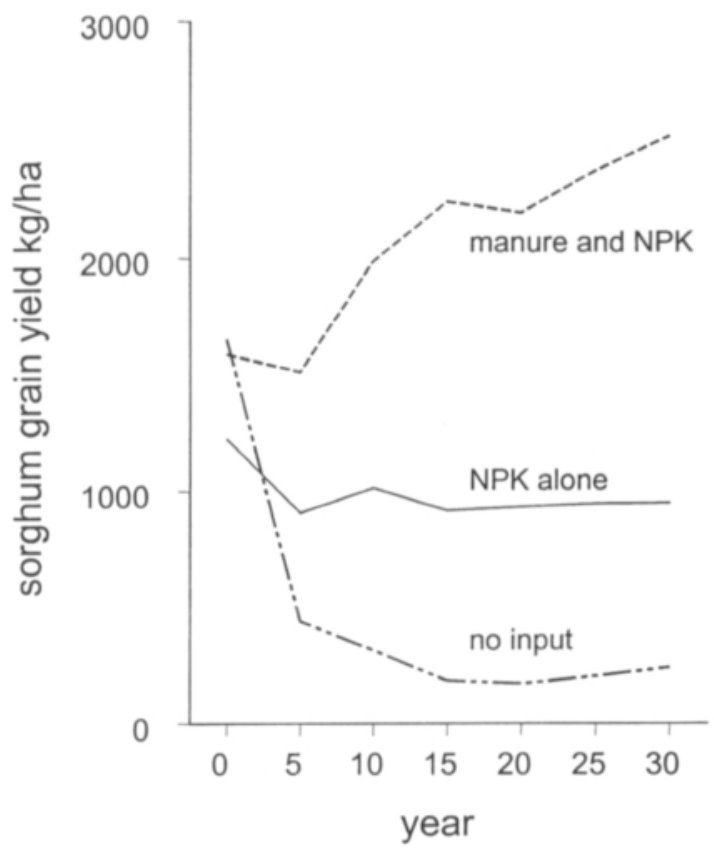

Fig. 1. Effects of applying manure and artificial fertilisers to sorghum crops in Burkina Faso over 30 years. A 3:1:1 ratio of NPK (nitrogen phosphorus potassium) was used in this experiment. Initial yields were apparently affected by previous cropping history; the long term trends show a characteristic decline in plots provided no inputs (Sedogo 1993).

marily in the urine. The potential benefits from urine and faeces are shown in Figure 2. These results were obtained by corralling six cattle in movable $4 \mathrm{~m} \mathrm{x} 4 \mathrm{~m}$ pens for one, two or three nights on plots of sandy soil in Niger. For comparison, faeces (manure without urine) equivalent in weight to that excreted by the penned cattle was deposited on other plots. Application of faeces to the nutrient-poor sandy soils substantially increased grain yields.

However, the most dramatic effect on yield was produced by the combination of faeces and urine. Yield increased in response to increased application rates of faeces and urine and also in response to increased available phosphorous because the urine raised soil $\mathrm{pH}$. The residual effects of faeces and urine continued to increase soil fertility in the second and third years after initial application (Powell et al. 1998). 


\section{AGRICULTURAL AND FOOD SCIENCE IN FINLAND}

Seminar in honour of the 100th anniversary of MTT

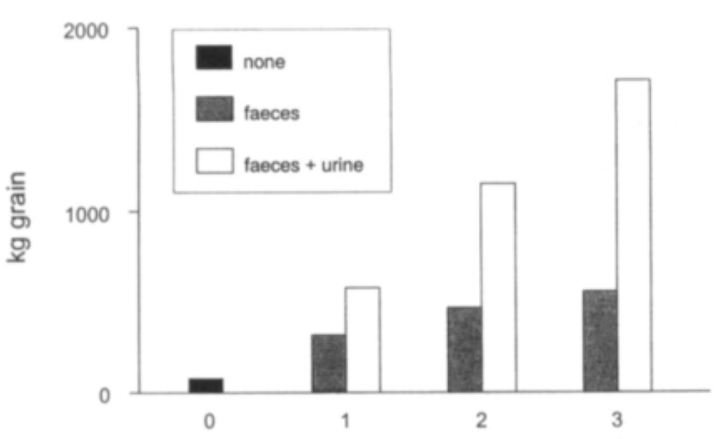

number of nights livestock were coralled at site

Fig. 2. Effects of cattle faeces and urine on pearl-millet grain yields in Niger (Powell et al. 1998).

Small-scale farmers in Asia face similar problems to those in West Africa: they, too, cannot afford to purchase large amounts of inorganic fertilisers to feed their soils to enable their cropping systems to remain productive and sustainable. Asian farmers face additional constraints imposed by the region's higher population densities. Farming in the humid and subhumid regions of Asia is characteristically done on tiny plots of land that are cropped continuously.

More livestock are raised in Asia than in any other region of the world. Animals are commonly kept in stalls in backyards rather than on range- or croplands. Livestock are managed in highly intensified systems purposely to produce manure as well as food traction. For example, sustainable small-scale farming in Java is based on use of livestock to produce manure to feed continuously cropped soils. The "kadang" animal enclosure houses from four to six sheep on a bamboo slatted floor over a pit where animal faeces, urine and rejected feed accumulate to form high-quality compost. This compost is used to fertilise the rice, maize and pulses that sustain the household (J. Tanner, pers. comm.).

In the late nineteenth century, after rapid population growth on Java forced farmers to move into marginal upland areas, the colonial government predicted widespread soil exhaustion and decline in yields. Despite such gloomy prophesies, these upland areas today represent $42 \%$ of the land used for annual crop production and support an average population density of some
600 persons per sq. $\mathrm{km}$. This is largely because the Javanese farmers integrated livestock production into their intensive cropping systems and devised systems for rearing livestock that effectively recycle nutrients in economically efficient ways.

\section{International livestock research}

The challenges of meeting increased demands for livestock products while protecting the national resource base are formidable. Research can help meet these challenges.

For most developed countries, including Finland, research-based interventions have transformed the livestock food production sector over the past 50 years by improving productivity, reducing costs and mitigating adverse environmental effects.

For most developing countries, the contributions of research have been limited. Knowledge and technologies that work in temperate developed countries are usually not directly transferable for the socioeconomic and agroecological conditions of developing countries. Moreover, few developing countries have the capacity to meet their own agricultural research needs.

These needs for appropriate research led three decades ago to the establishment of the Consultative Group for International Agricultural Research (CGIAR). The CGIAR is a consortium of more than 55 donors, including Finland, which provide US\$ 350 million per year to support 16 international agricultural research centres. These centres, working in partnership with national research institutes in both developed and developing countries, address the biotechnical, socioeconomic and agroecological constraints on agricultural development. The goals of the CGIAR are poverty alleviation, food security and environmental protection.

The International Livestock Research Institute (ILRI) is one of the 16 centres supported by the CGIAR. ILRI was established in 1995, build- 
Vol. 7 (1998): 197-206.

ing on the resources of the International Livestock Research Centre for Africa (ILCA) and the International Laboratory for Research on Animal Diseases (ILRAD), which had been established in the mid-1970s to address constraints on African livestock production.

ILRI has a global mandate for research to improve the productivity of smallholder livestock systems and protect the natural resources that support these systems. ILRI's research agenda for the medium term draws on capacity and comparative advantage in four areas: ruminant genetics, ruminant health, ruminant feed resources and crop-livestock systems. The first three areas of component research involve upstream biological/animal-level research, while the strategic and applied crop-livestock systems research draws from and feeds back to the outputs of the biological research (ILRI 1997b).

\section{Ruminant genetics}

ILRI has a successful record of research into disease resistance and is a world leader in research on resistance to haemoparasitic disease. Emphasis is on characterising indigenous livestock genetic resources for disease-resistance traits and using genetic markers for marker-assisted introgression to produce novel livestock genotypes combining trypanosomosis resistance with "other" desirable traits. Research on characterisation of livestock genetic resources is closely linked with FAO's global initiative for domestic animal diversity. Research on identification of correlations between both trypanotolerance and helminthiasis resistance and other disease resistance traits and on the identification of genes responsible for trypanotolerance and helminthiasis resistance is an important activity.

\section{Ruminant health}

Research on ruminant health includes laboratory-based strategic research on development of vaccines and diagnostics, field-based studies to identify recommendation domains for animal health interventions and testing vaccine efficacy. ILRI focuses on trypanosomosis and East Coast fever (ECF) and on the other major tickborne diseases of the developing world. Major emphasis is given to developing and validating improved diagnostics for haemoparasitic diseases, field testing vaccines in East Africa and evaluating antigens of Theileria parva to develop an improved second-generation vaccine. Research continues on the isolation and characterisation of protective antigens for immunisation against trypanosomosis. ILRI is also investigating and defining the complex interactions between health, genetics and nutrition at the smallholder farmer level. These studies are incorporated in the work on crop-livestock production systems.

\section{Ruminant feed resources}

Poor nutrition due to poor-quality feeds and fluctuating feed supply limits the productivity of tropical livestock. The need for greater quantities of quality fodder requires new forages and feeding strategies that enhance the efficiency with which conventional on-farm feed resources are used. Strategic research on the estimation of nutritional value and use of forages and crop residues is linked with new research capacity in rumen microbiology and phytochemistry. Rumen ecology research concentrates on identifying and detoxifying antinutritional factors in fodder trees, forages and crop residues. Research on forage genetic resources includes molecular genetic characterisation and phytochemical evaluation. Research on conservation emphasises in situ conservation, including effects of grazing on forage biodiversity.

\section{Interdisciplinary crop-livestock systems research}

ILRI's crop-livestock systems research takes a holistic production-to-market approach. $\mathrm{Re}$ - 


\section{AGRICULTURAL AND FOOD SCIENCE IN FINLAND}

Seminar in honour of the 100th anniversary of MTT

search outputs are developed and tested interactively with national partners. Systems research in ILRI incorporates socio-economic and livestock policy analysis with biological research on genetics, health and feed resources. Emphasis is on natural resource management and nutrient cycling research to meet demands for production from limited land area. ILRI coordinates its systems research across agro-ecological zones to facilitate transregional analysis and to broaden the recommendation domains for the research outputs.

The CGIAR has identified Asia and Africa as high-priority regions for future research. Crop-livestock systems research continues to focus on Africa and will be expanded to Asia through ecoregional consortia, with particular emphasis on feed resources research for smallholder dairy and small ruminents in South Asia and on the integration of livestock into rice-based or tree-crop systems in the uplands of Southeast Asia.

This research includes the following projects:

- increasing returns to livestock research through systems analysis and impact assessment;

- policy analysis for improving productivity and sustainability of crop-livestock systems;

- ecoregional projects to improve productivity and sustainability of crop-livestock systems in Africa, Asia and Latin America;

- improving livestock productivity under disease risk; and

- improving productivity and sustainability of smallholder dairy systems

As part of ILRI's research on crop-livestock systems, ILRI serves as the lead centre for the Systemwide Livestock Programme (SLP). The SLP is a CGIAR research initiative to improve livestock feed resources and natural resource management in crop-livestock systems. The SLP works through crop centres and their national partners in ecoregional consortia. The SLP research themes link high-priority work on feed resources and natural resource management and facilitate transregional analyses and technology transfer. These themes include:

- improvement of the nutritive value of crop residues;

- improvement of feed resources for smallholder dairying;

- matching livestock nutritional requirements and local feed resources in different agroecological zones;

- nutrient recycling that sustains cropping systems;

- use of forage legumes in cropping systems;

- use of fodder shrubs for livestock feed; and

- practices and policies that improve management of fragile lands.

\section{Strengthening partnerships}

With a few exceptions, livestock research capacity is not well developed in national research institutes, especially in Asia and Africa. Therefore, ILRI gives priority to strengthening capacity for livestock research through training and information services. ILRI scientists also work in close partnership with national scientists from both developing and developed countries. For example, collaboration with Finnish scientists on ruminant nutrition research has proven particularly productive over the past decade.

\section{Conclusions}

Demand for livestock products - meat, milk and eggs - will substantially increase in the foreseeable future. Increases will be greatest in developing countries where current levels of consumption are relatively low. Increased demand will be fuelled by population increase, income growth and urbanisation. Meeting this demand will place more stress on the natural resources supporting agriculture, as well as increasing chances for pollution and other environmental problems. 
Vol. 7 (1998): 197-206.

The solution is not to deny families in developing countries the benefits of livestock products long enjoyed by families in developed countries. Through research, involving global part- nerships of scientists, knowledge and technologies can be produced to improve livestock productivity in economically feasible and environmentally sustainable ways.

\section{References}

Brown, L.R. 1995. Facing food scarcity. In: World Watch, Washington, D.C. November/December. p. 10-20.

Delgado, C., Coubois, C. \& Rosegrant, M. 1998. Global food demand and the contribution of livestock as we enter the new millennium. In: Gill, E.M. et al. (eds.). Food, lands and livelihoods: Setting research agendas for animal science. Proceedings BSAS/CTA International Conference, Nairobi, Kenya. (in press).

FAOSTAT 1997. Agricultural databases. Food and Agricultural Organisation, Rome.

Fitzhugh, H.A., Hodgson, H.J., Scoville, O.J., Nguyen, T.D. \& Byerly, T.C. 1978. The role of ruminants in support of man. Winrock International, Morrilton, Arkansas. $136 \mathrm{p}$.

ILRI 1997a. Livestock and soil fertility: exploiting the natural balance. International Livestock Research Institute. Nairobi, Kenya. 7 p.

- 1997b. ILRI Medium-term plan 1998-2000. International Livestock Research Institute. 75 p.

Powell, J.M., Ikpe, F.N., Somda, Z.C. \& FernándezRivera, S. 1998. Manure and urine effects on pearl millet yield and soil chemical properties. Experimen- tal Agriculture (in press).

Rosegrant, M.W., Agcaoili-Sombilla, M. \& Perez, N. 1995. Global food projections to 2020: Implications for investment. 2020 Vision Discussion Paper No. 5. International Food Policy Research Institute, Washington, D.C.

Sédogo, P.M. 1993. Evolution des sols ferrugineux lessivé sous culture: influences des modes de gestion sur la fertilité. Thèse Doctorat, Université Nationale de Côte d'Ivoire, Abidjan.

Sere, C. \& Steinfeld, H. 1996. World livestock production systems: current status, issues and trends. FAO Animal Production and Health Paper 127. Food and Agricultural Organisation, Rome. 82 p.

USDA 1990. World agriculture: Trends and indicators. 1970-1989. Agriculture and Trade Analysis Division, Economic Research Service, U.S. Department of Agriculture. Statistical Bulletin No. 815.

Winrock 1992. Assessment of animal agriculture in SubSaharan Africa. Winrock International. Morrilton, Arkansas. 125 p. 


\title{
AGRICULTURAL AND FOOD SCIENCE IN FINLAND
}

Seminar in honour of the 100th anniversary of MTT

\section{SELOSTUS}

\section{Kotieläintuotannon osuus kehitysmaiden ruoantuotannosta}

\author{
Hank Fitzhugh \\ International Livestock Research Institute, Kenia
}

Maailman maataloustuotteiden kaupan arvosta $40 \%$ koostuu kotieläintuotteista - lihasta, maidosta, munista ja eläinkuiduista. Kotieläintuotteiden sisältämät välttämättömät aminohapot, vitamiinit ja hivenaineet ovat ravitsemuksellisesti tasapainoisen aterian perusta. Lisäksi viljelytekniset toimenpiteet, kuten kotieläinten käyttö vetojuhtina ja lannan käyttö lannoitteena, lisäävät satoa varsinkin kehitysmaissa. Näin saatu suurempi sato taas osaltaan edesauttaa kehitysmaiden ruoantuotantoa. Kotieläintuotteista saadun energian ja valkuaisen suhteellinen osuus ravinnon energiasta ja valkuaisesta on teollisuusmaissa keskimäärin kaksinkertainen kehitysmaihin verrattuna. Väestönkasvu, käytettävissä olevien tulojen kasvu ja väestön muutto kaupunkeihin lisäävät kotieläintuotteiden kysyntää kehitysmaissa. Niinpä viimeisen vuosikymmenen aikana kotieläintuotteiden kulutus on jyrkästi lisääntynyt kehitysmaissa, mutta sen sijaan hieman vähentynyt teollisuusmaissa, joissa jo nyt kulutetaan paljon kotieläintuotteita. Lisääntynyt kulutus kehitysmaissa lisää tuottajien tuloja, mutta samalla saastuminen, eroosio, liikalaiduntaminen ja metsien hakkuut rasittavat ympäristöä. Tutkijoiden ja tutkimuslaitosten kansainvälisellä yhteistyöllä voidaan varmistaa, että kehitysmaiden lisääntyvään kotieläintuotteiden kysyntäăn vastataan taloudellisesti kannattavalla ja ympäristön huomioon ottavalla tavalla. 